\title{
PREFACE TO THE FIRST EDITION
}

On a windy day in December 1989 , just over eleven years since I had first taken the desert highway from Cairo to Alexandria, I sat with my aunt by the side of the road. My father had disappeared with the driver of our rented car, an agricultural engineer, and my husband to pick out the sheep we had just arranged to purchase. Meanwhile, my aunt and I bided our time.

Now, as in 1978, my father was accompanying me to visit a Bedouin family who lived not far off this desert road, people we had initially met together but with whom, in the intervening decade, I had lived on and off for more than two years. This was his first return visit to the community. Agreeing with me that it was only proper that he pay a call to express his appreciation for what they had done to help me, my father had routed himself through Egypt while on a trip to the Middle East. My father's sister had flown over from Jordan to see us and was curious to know the people with whom I had spent so much time. And my husband, although he had read most of what I had written about the families we were going to visit, including a draft of this book, had never met them. I wanted finally to introduce him to them.

When we set off again I was excited and proud. I was proud that we would pull up to the house in a Mercedes; it would confirm that I came from a good family and had, moreover, made a good marriage. (On my own, I had always straggled in from the bus and hot taxis that left me off on the road.) I was even prouder that we had a sheep of respectable size knocking about in the trunk of the car and that I sat wedged in the back seat with cartons full of unshelled peanuts, green tea, candy, and a jumble of combs, mir- 
rors, kerchiefs, colognes, hairclips, pens, and cigarette lighters. My Bedouin friends would recognize that these were no ordinary gifts. This combination was the appropriate offering on the important occasion of a bride's first postmarital visit home, and I was pleased with myself for having arranged everything so well.

I was, I knew, a bit old for all this, and I wondered at my own reaction. Why should returning not just with members of my own family but as a daughter and new bride-a consummately patriarchal configuration-make me feel good? Had I not, years ago, established myself as a scholar and developed with the Bedouin family a relationship that was quite independent of these people who were accompanying me? Had I not distanced myself from that first encounter in which, shy, embarrassed, and feeling distinctly unlike an anthropologist, I had sat in the back of a van while my father discussed with the men of this family my need for hosts to help me learn about "the traditions and customs" of the Awlad "Ali Bedouin? Had I not moved far enough beyond the dutiful daughter role I had once played to disagree with my host when he, assuming I shared his prejudices, criticized Europeans for their moral failings? On my last visit, when he complained about the lack of concern Europeans showed for their families, I had argued that the progressive breakdown of the extended family could be attributed to the need for mobile labor under modern capitalism; it could, I said, happen even to the Awlad 'Ali. As a feminist, I had also chided him for leaving his wives and daughters undernourished while he lavished attention on his guests. Had this community not registered its new view of me when some had asked me, as a respected outside authority, to present to their disdainful Egyptian compatriotswho consider them bandits or primitives - the truth about Bedouin social life and values?

Yet I was excited because I could anticipate their response to this visit. They consider family important, and part of what had made me acceptable to them in the first place was that they had met my family. My background as the daughter of an Arab and a Muslim had also been significant, compensating for my own apparent 
cultural incompetence. Arriving now from America with more family members would confirm me as, like them, not simply an individual, but part of a family, and one with which they had already established mutual ties. Over the years, I had often heard them discuss my father's concern for me and confidence in them; they would interpret his visit as an acknowledgment of their generosity and integrity.

I knew they would also be pleased to see me finally married. Most of the adolescent girls with whom I had first been associated were now married, each with one or two children. A bride whom I had helped welcome into the household was now the mother of five. The women of the family, and even some of the men, had often expressed concern that I had not married and begun a family of my own.

Furthermore, I was certain that they would appreciate our gesture of honoring them with these gifts. They knew that nonBedouins do not offer sheep as gifts; they would realize that I had learned this sign of respect from them. And only the Awlad 'Ali celebrate the postmarital visit in this way. The symbolism would be clear. We would be affirming both a sort of belonging to this community and, more importantly, this particular family's status as "close kin" of mine. In $1988 \mathrm{I}$ had scribbled on a sheet of paper a list of things a bride is traditionally expected to bring on her postmarital visit home. The woman doing the itemizing had teased me at the time about why I wanted this information: "Lila," she had joked, "we expect you to bring us these things when you get married!" She would not be expecting me to follow through, but she would remember our list.

This visit was of great personal importance because I hoped finally to bring together two parts of my life. The Bedouin families with whom I had lived had just as little knowledge of my social world in the United States as they had of my academic life, a life to which, in a peculiarly objectified form, they were so central. Introducing my husband to them was a way for me to begin to join the worlds. I was especially anxious that they accept him and 
condone my marriage to a foreigner, with its implications for my primary identity. Although my husband had done research in Egypt and speaks Arabic, he is English. And I knew they felt strongly that I, in their eyes an Arab Muslim woman, should marry within the community. I hoped that my father's very presence would indicate his approval of the match and validate my husband; but I could not be sure how they would react when confronted with the finality of my dual identity and divided loyalties.

I was relieved and touched by what happened. Predictably, the Haj, my Bedouin host, regaled us with his tales about the British troops in the Western Desert during the Second World War. He also politely inquired whether my husband knew his British friends: Wilfred Thesiger, the explorer, who had indeed once passed through, and Mark Allen, a British diplomat in Egypt in the early I980s who had enjoyed falcon hunting with the Haj. The unexpected thing the Haj did, however, was to tell some stories I had never heard before: stories about the origins of the British, suggesting that the ancestors of many English people, including some of the royal family, had been Arabs. We did not quite realize what he was doing until, several hours later as we rose to leave after lunch, he looked closely at my husband and then turned to his brother for confirmation. "Just look at his face," he said. "You can see his Arab blood!"

In his own way, the Haj had sought to bring my two worlds together, enfolding the foreign world into his to draw me back in. The distance between these cultural and geographic worlds had been decreasing over the last decade anyway. The Haj's own daughter had recently married a young man whose older brother was studying medicine in England. Electricity had been tapped from the new power lines joining the coastal towns; the new cinder-block houses cropping up on what had been open land all had television sets in their front rooms. The Awlad 'Ali Bedouins, as former pastoralists moving herds of sheep, goats, and sometimes camels and involved in trade between Libya, the oases of the Western Desert, and the Nile Valley from Alexandria to Upper 
Egypt, had never been isolated. Yet they were now more closely integrated into Egyptian state institutions and the national economy than even ten years earlier.

Many ethnographies open with the trope of arrival. My first book, Veiled Sentiments, began with a description of the road one took to the Bedouin hamlet that housed the families whose social world I would describe and analyze. Second books on the same community often begin with the image of return and the radical changes the author encounters after a long absence. I could not, however, follow this formula because less than a year had passed since my last visit and $I$ had just spent five months in the community only two years earlier. Unlike my father, I had seen the desert highway go from two to four lanes and was not surprised to see the toll booths. I knew how the Haj detested this new road with its radar speed traps. I had seen the gradual extension of irrigation canals and the conversion of much of the barren land around the community into orchards. As the region became more crowded, fewer families pitched tents near their houses. I had also seen the sudden growth of the nearby market town where my host's brothers now owned a building that housed a café and several stores. They had come to find property investment more lucrative than the sheep herds that had earlier sustained them. Now only one brother still kept herds, and when one day he was kicked by one of his camels, even his old mother begged him to get rid of them. Their time had passed, she said.

I had written earlier about the Awlad 'Ali tribes of the Western Desert as culturally and linguistically distinct both from the Bedouin groups of Sinai and the Eastern Desert and from the Egyptians living in the villages and towns of the Nile Valley. The Awlad 'Ali trace their origins to Libya, and many would insistently point out their difference from the people who ran the country in which they found themselves uneasy citizens, resentful of increasing restrictions. Their children, however, who are in contact with nonBedouins in government schools, seemed sometimes ambivalent about the features that set the Bedouins apart: the strength of the 
bonds of kinship, the control of elder kin over younger, the independence that marks men's honor, and the voluntary veiling and separation from men that indexes women's respectability.

The younger generation was becoming aware, as readers of this book should be too, of how marginal their way of life is, whether to the rest of Egypt or to the Arab world as a whole. If pastoralists in the mid-twentieth century represented no more than I percent of the population of the Middle East, their values and their ways of organizing sociopolitical and economic life are now those of an even smaller minority. This is clearest in the situation of women. In most of Egypt working women in the r980s were struggling with the competing demands of employment and family: running household farms while their men worked as migrant laborers in Saudi Arabia, sewing clothes, peddling on the street, battling the crowds in public transportation to get to their jobs in offices and wealthy people's homes, or finding professional careers as politicians, businesswomen, teachers, and medical doctors-some of whom might also be feminist leaders or Islamic activists. For the women in the families I know, however, these kinds of lives are only distant possibilities. Given their differences from the majority of Middle Eastern women, what purpose might be served by recounting, as I do in Writing Women's Worlds, their stories?

This book is intended to present, in the form of a narrative ethnography made up of these women's stories and conversations, a general critique of ethnographic typification. I was searching, like other anthropologists working today, for a new ethnographic style; I was also intrigued by the insights on method and voice emerging from feminist theorizing and sympathetic to concerns in Middle East studies about the way Arab societies tend to be portrayed. I decided to explore how the wonderfully complex stories of the individuals I had come to know in this community in Egypt might challenge the capacity of anthropological generalizations to render lives, theirs or others', adequately. The resulting series of narratives is organized around five anthropological themes associated with the study of women in the Arab world: patrilineality, polygyny, re- 
production, patrilateral parallel-cousin marriage, and honor and shame. Yet rather than the chapter titles explaining the stories, the stories are meant to undo the titles.

The narrative chapters are preceded by an introduction written in the more conventional form of an academic essay that locates the work in its appropriate theoretical and political contexts. My intention in this is to alert readers to the possibility of reading the book in a particular way. The narrative chapters are not meant to be just entertaining or illuminating stories about Bedouin life in the I980s; they are also critical commentaries on anthropological modes of understanding human existence. As representations of Bedouin life, these narratives are organized deliberately in terms of a set of goals determined by the context in which they will be read, not the context in which they occurred. That is, I expect the audience-which I assume will be mostly Western or Westerneducated, coming to the text informed by anthropology (and its current critics), feminism (and its internal dissenters, including Third World feminists), and Middle East studies (with its awareness of the problems of orientalism) - to approach the book critically, keeping in mind questions about the politics of ethnographic representation and sociological description, problems of feminist aspiration and method, and assumptions about the Muslim Middle East.

Although it opens with an introduction, the book has no formal conclusion. We plunge into the stories in chapter 1 , and remain with them through the end of the book. A discursive conclusion would have given closure; it would have provided the reader with "the meaning" of all these stories about parents, children, husbands, wives, conflicts, joys, and hopes. Busy readers could then have skipped from the introduction to the conclusion, assuming that they had an adequate gloss for what was sandwiched between. Such a concluding commentary, pronouncing the lessons of all these rich and complex stories, would have restored the superiority of the interpretive/analytical mode being questioned by the very construction of narratives, would have reestablished the familiar 
authority of the expert's voice, and, most troubling, would inevitably have contained the stories. That I selected and organized them according to the themes designated by the chapter headings seemed limiting enough to their meanings. To have tried to sum up their significance would have reduced them further. It would, in the end, have diminished their power and their potential to overflow our analytical categories. In life, in their tellings in Egypt, these stories and conversations did not occur in themes, at least not these themes. And although I wanted the tales to be able to speak to a set of intellectual debates in various fields in the United States and Europe in the I990s, I also wanted to let them be more. 